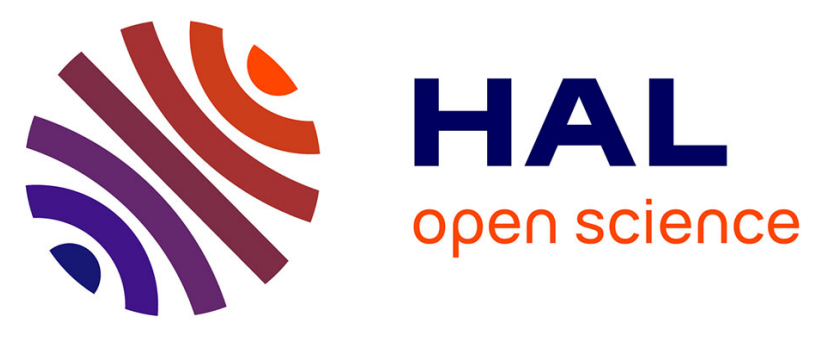

\title{
Culture of human adipose tissue explants leads to profound alteration of adipocyte gene expression.
}

Stéphane Gesta, Karine Lolmède, Danièle Daviaud, Michel Berlan, Anne

Bouloumié, Max Lafontan, Philippe Valet, Jean-Sébastien Saulnier-Blache

\section{To cite this version:}

Stéphane Gesta, Karine Lolmède, Danièle Daviaud, Michel Berlan, Anne Bouloumié, et al.. Culture of human adipose tissue explants leads to profound alteration of adipocyte gene expression.. Horm Metab Res, 2003, 35 (3), pp.158-63. 10.1055/s-2003-39070 . inserm-00110141

\section{HAL Id: inserm-00110141 https://www.hal.inserm.fr/inserm-00110141}

Submitted on 4 Sep 2009

HAL is a multi-disciplinary open access archive for the deposit and dissemination of scientific research documents, whether they are published or not. The documents may come from teaching and research institutions in France or abroad, or from public or private research centers.
L'archive ouverte pluridisciplinaire HAL, est destinée au dépôt et à la diffusion de documents scientifiques de niveau recherche, publiés ou non, émanant des établissements d'enseignement et de recherche français ou étrangers, des laboratoires publics ou privés. 


\section{Hal author manuscript}

Culture of human adipose tissue explants leads to profound alteration of adipocyte gene expression

Stéphane Gesta, Karine Lolmède, Danièle Daviaud, Michel Berlan, Anne Bouloumié, Max Lafontan, Philippe Valet and Jean Sébastien Saulnier-Blache*.

I.N.S.E.R.M U317, Institut Louis Bugnard, Université Paul Sabatier, CHU Rangueil, Batiment L3, 31403, Toulouse cedex 04, France.

Running Title: adipocyte gene expression in human adipose tissue explants

* Corresponding author

Tel: (33) 562172956

Fax: (33) 561331721

Email: saulnier@,rangueil.inserm.fr 


\begin{abstract}
:
Primary culture of adipose tissue has often been used to investigate pharmacological or nutritional regulation of adipocyte gene expression. Possible alteration of adipocyte gene expression by primary culture by itself has not been explored in details. In order to address this point, explants were prepared from human subcutaneous adipose tissue issued from plastic surgery, and maintained for 0 to $48 \mathrm{~h}$ in DMEM supplemented with $10 \%$ serum. At different time points adipocytes were isolated from the explants by collagenase digestion and mRNA expression and lipolysis were studied. Culture was associated with an accumulation of Tumor Necrosis Factor-a $(\mathrm{TNF} \alpha)$ in the culture medium, an increase in anaerobic glycolysis, and an increase in the basal lipolysis. In parallel, a rapid and dramatic decrease in the level of mRNA encoding for several adipocyte-specific proteins such as Adipocyte Lipid-Binding Protein, Hormone-Sensitive Lipase, Lipoprotein Lipase, Peroxisome Proliferation Activating Receptor- $\gamma 2$, was observed in isolated adipocytes. These down-regulations were reminiscent of a dedifferentiation process. In parallel, primary culture was associated with an increase in adipocyte $\beta$-actin, $\mathrm{TNF} \alpha$, Glucose transporter-1 and Hypoxia Induced Factor- $1 \alpha$ mRNAs. Treatment of explants with agents that increase cAMP (isobutylmethylxanthine and forskolin), prevented against $\mathrm{TNF} \alpha$ production and expression, as well as against cultureinduced alterations of adipocyte gene expression. These data show that primary culture of human adipose tissue explants dramatically alters adipocyte gene expression.
\end{abstract}




\section{Introduction}

Clarification of the mechanisms of long-term adaptations of ex vivo mature adipocytes to hormonal, and nutritional factors requires culture methods that preserves the function and gene expression of the adipocytes over a time course of hours to days. Freshly isolated mature adipocytes can be used to investigate short-term (within 1 or 2 hours) regulation of adipocyte metabolism (lipolysis, lipogenesis, glucose transport) or secretion, but are not appropriate to study long-term regulations because of their limited viability over long time course of culture (several hours to days). Primary culture of adipose tissue explants represents an interesting alternative to improve adipocyte viability because of the partial preservation of its tissue environment. Several reports have indeed demonstrated that this type of culture allows preserving adipocyte metabolism over several days (1-3) without major alterations.

Based on these observations, an increasing number of laboratories are now using the culture of adipose tissue explants to study the influence of various pharmacological of nutritional factors on adipocyte gene expression (4-12). However, in these different studies, little attention has been paid to the consequences of the primary culture by itself on adipocyte gene expression. Primary culture of adipose tissue is indeed preceded by several steps (surgery, transport, dissection) constituting potential aggression (thermic shock, hypoxia) which could alter normal adipocyte gene expression. In addition, several reports have shown that adipose tissue explants in culture produce relatively high amount of Tumor Necrosis Factor-a $(\mathrm{TNF} \alpha),(13-15)$ a cytokine known to inhibit and/or reverse adipocyte differentiation (16-18)

In the present study we analyzed the influence of primary culture of human adipose tissue on the expression of several genes specifically in adipocytes. For that, adipocytes were isolated by collagenase digestion from human subcutaneous adipose tissue explants that have 
been maintained in primary culture for various period of time (0 to $48 \mathrm{~h})$. We observed that primary culture was associated with a profound alteration of several adipocyte genes reminiscent of a dedifferentiation process. This effect was largely prevented by treatment of explants with agents that increase cAMP. 


\section{Materials and Methods}

\section{Culture of explants}

Human subcutaneous adipose tissue was obtained from healthy, drug free non-obese (BMI $23.6 \pm 1.1 \mathrm{~kg} / \mathrm{m}^{2}$, age $41.3 \pm 5.2, \mathrm{n}=9$ ) women, undergoing abdominal dermolipectomy for plastic surgery. After rapid transportation in the laboratory adipose tissue was carefully dissected out from skin and vessels, and cut in small pieces (average weight 20-50 mg) under sterile conditions. Explants were placed at $37^{\circ} \mathrm{C}$ for 0 to $48 \mathrm{~h}$ in a humidified atmosphere containing 7\% CO2 in $100 \mathrm{~mm}$ diameter dishes (7 $\mathrm{g}$ in $12 \mathrm{ml}$ ) in DMEM supplemented with $10 \%$ fetal calf serum. The medium was changed after $24 \mathrm{~h}$ culture. Culture aliquots of the culture media were collected to measure the rate of disappearance of glucose $(4.5 \mathrm{~g} / \mathrm{l}$ at time 0 ), the rate of production of lactate, and the accumulation of $\mathrm{TNF} \alpha$. Glucose was measured using a colorimetric assay (Merck). Lactate was measured using the Lactate Reagent (Sigma Diagnostic). TNF $\alpha$ was measured using EIA (Immnunotech, Beckman Coulter)

\section{RNA extraction from isolated of adipocytes}

At different time points, adipose tissue explants were digested (7g in $10 \mathrm{ml}$ ) in DMEM containing $0.5 \mathrm{mg} / \mathrm{ml}$ type II collagenase (Sigma) and 1\% bovine serum albumin (Sigma) for 30 to $40 \mathrm{~min}$ at $37^{\circ} \mathrm{C}$ under constant shaking. At the end of the incubation period the reaction was stopped by dilution in DMEM, filtered on a silk screen in order to retain undigested explants and isolated adipocytes were separated from the stroma-vascular fraction by floatation. The floating packed cells were washed twice with DMEM. Total RNA was extracted from isolated adipocytes using Rneasy Kit (Qiagen) according to the instructions of the company except that the fat cake was removed by centrifugation before loading the purifying columns. 


\section{Determination of adipocyte size}

An aliquot of isolated adipocytes was photographed under microscope using a digital camera connected to an image analyzer (Visiolab). Mean fat cell diameter was determined by measuring the diameter of at least 100 cells.

\section{Lipolysis of isolated adipocytes}

For lipolysis experiments, the process of isolation of adipocytes was identical than for RNA extraction exept that DMEM was replaced by Krebs Ringer bicarbonate buffer supplemented with $6 \mathrm{mM}$ glucose and $3.5 \%$ bovine serum albumin (this buffer was called KRBA). Isolated adipocytes were brought to a suitable dilution (2000-3000 cells/assay) in KRBA for lipolysis assays and incubated with pharmacological agents in a final volume of $100 \mu \mathrm{l}$ and for $90 \mathrm{~min}$ at $37^{\circ} \mathrm{C}$. At the end of the incubation, 20 to $50 \mu \mathrm{l}$ aliquots of the infranatant were taken for glycerol determination (19).

\section{Northern blot analysis}

32P-labelled probes were obtained by Nick-translation of cDNA fragments purified from the coding region of: rat ALBP, human HSL, human LPL, and human $\beta$-actin. Twenty $\mu \mathrm{g}$ of total RNAs were separated by electrophoresis in $1 \%$ agarose gel containing $2.2 \mathrm{M}$ formaldehyde. Before transfer, the gel was soaked in an ethidium bromide solution to label ribosomal RNA and verify that the amount of total RNA loaded on the gel was equivalent from one sample to another. RNAs were then transferred onto a nylon membrane (Schleicher and Schuell, Dassell, Germany) and UV-crosslinked. The blot was incubated overnight at $68^{\circ} \mathrm{C}$ in hybridization buffer containing $0.5 \mathrm{M} \mathrm{Na}_{2} \mathrm{HPO}_{4}-12 \mathrm{H}_{2} \mathrm{O}, 1 \mathrm{mM}$ EDTA, $7 \%$ SDS, $1 \%$ 
BSA, ${ }^{32} \mathrm{P}$-labelled cDNA probes $\mathrm{pH}$ 7. The blot was finally washed at a final stringency of $0,5 \mathrm{XSS} ; 0,1 \% \mathrm{SDS}$ at $65^{\circ} \mathrm{C}$ and autoradiographied. 


\section{RT-PCR analysis}

One $\mu \mathrm{g}$ RNA was reverse transcribed for $60 \mathrm{~min}$ at $37^{\circ} \mathrm{C}$ using Superscript II RNase $\mathrm{H}^{-}$ Reverse Transcriptase (RT) (Gibco BRL life technologies) in $20 \mu$ l volume containing $4 \mu 1$ of $5 \mathrm{X}$ first stand buffer (250 mM Tis- $\mathrm{HCl}, \mathrm{pH} 8.3,375 \mathrm{mM} \mathrm{KCl}, 15 \mathrm{mM} \mathrm{MgCl}$ ), $1 \mu \mathrm{DTT}$ $0.1 \mathrm{M}, 1 \mu \mathrm{l} \mathrm{dNTP}(10 \mathrm{mM}), 1 \mu \mathrm{l}$ oligo $(\mathrm{dT})_{12-18}(0.5 \mu \mathrm{g} / \mu \mathrm{l})$ and 100 units RT. A minus RT reaction was performed in parallel to ensure the absence of genomic DNA contamination, which was always the case in the present study.

$\mathrm{RT}+$ and RT- reaction were subjected to Polymerase Chain Reaction (PCR). PCR was carried out in a final volume of $50 \mu$ c containing $3 \mu 1$ of cDNA, $1 \mu 1 \mathrm{dNTP}(10 \mathrm{mM}), 5 \mu 1$ 10x PCR buffer (10 mM Tris-HCl, $\mathrm{pH} 9,50 \mathrm{mM} \mathrm{Kcl}$ and 0,1\% Triton X-100), $3 \mu \mathrm{MgCl} 2$ (25 $\mathrm{mM}), 1.5 \mu \mathrm{l}$ sense and $1.5 \mu \mathrm{l}$ antisense specific oligonucleotide primers $(10 \mu \mathrm{M})$ and 1.25 unit of Taq DNA polymerase (Promega).

Conditions for the PCR reaction consisted in an initial denaturation step at $94^{\circ} \mathrm{C}$ for 2 min, followed by $\mathrm{n}$ (depending on target gene) cycles composed of $1 \mathrm{~min}$ at $94^{\circ} \mathrm{C}, 1 \mathrm{~min}$ at the annealing temperature of $\mathrm{T}^{\circ} \mathrm{C}$ (depending on target gene) and a final extension at $72^{\circ} \mathrm{C}$ for $6 \mathrm{~min}$.

Annealing temperature (T) and number (n) of PCR cycles (optimized for each couple of primer): $\operatorname{PPAR} \gamma 2: 60^{\circ} \mathrm{C}, 25$ cycles; $\mathrm{TNF} \alpha: 57^{\circ} \mathrm{C}, 25$ cycles; Glut-1: $60^{\circ} \mathrm{C}, 33$ cycles; HIF- $1 \alpha$ : $60^{\circ} \mathrm{C}, 27$ cycles. PCR products were separated on $1.5 \%$ agarose gel and amplification products were visualized with ethidium bromide. Primer sequences and expected size of PCR product:

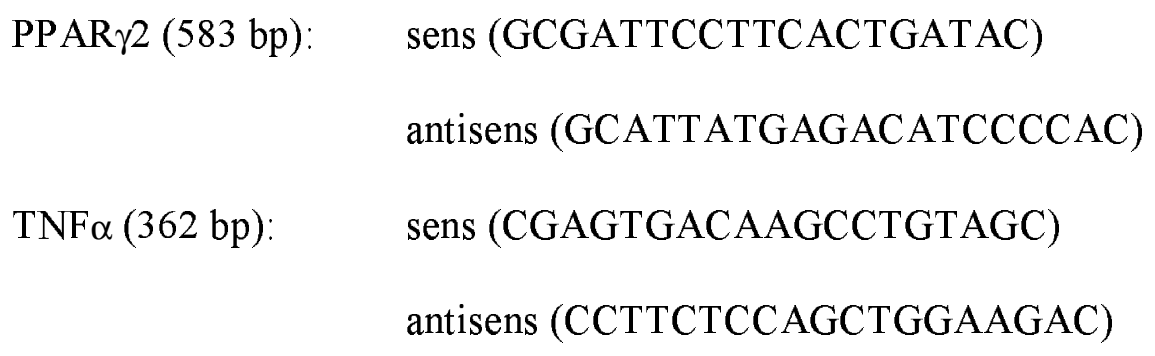


$\begin{array}{ll}\text { Glut-1 (410 bp): } & \text { sens (CCCCTTCCCATCTCTTCCTA) } \\ & \text { antisens (CCTCCTACCCTCAATCCACA) } \\ \text { HIF-1 } \alpha(407 \mathrm{bp}): & \text { sens (GTGGTAGCCACAATTGCACA) } \\ & \text { antisens (CCAACAGGGTAGGCAGAACA) }\end{array}$ 


\section{Results}

Subcutaneous adipose tissue was originating from female patients undergoing plastic surgery. Adipose tissue was rapidly (about $10 \mathrm{~min}$ ) transported in the laboratory, and dissected out in small explants which were cultured for various period of time ( 0 to $48 \mathrm{~h}$ ) in serum supplemented DMEM. At different time point, the culture medium was collected (for measurement of glucose, lactate and $\mathrm{TNF} \alpha$ ), and adipocytes were isolated from the explants following collagenase digestion. Total RNAs were extracted from isolated adipocytes and potential alterations in mRNA level were analyzed by Northern blot or RT-PCR.

\section{Analysis of culture medium composition}

Previous studies have shown that adipocytes in culture are able to secrete TNF $\alpha$ (1315). $\mathrm{TNF} \alpha$ was indeed found in relatively high amount in the culture medium after $48 \mathrm{~h}$ culture of adipose tissue explants: $726.3 \pm 66.2 \mathrm{pg} / \mathrm{ml} / \mathrm{g}$ of tissue $(\mathrm{n}=5)$. In parallel, a timedependent increase in glucose utilization ( $29 \mathrm{mg} / \mathrm{l} / \mathrm{h}$ after $6 \mathrm{~h}$ versus $35 \mathrm{mg} / \mathrm{l} / \mathrm{h}$ after $24 \mathrm{~h}$ ) by the explants was observed. This was associated with an accumulation of lactate $(0.52 \mathrm{~g} / \mathrm{lafter}$ $6 \mathrm{~h}$ and $1.96 \mathrm{~g} / \mathrm{l}$ after $24 \mathrm{~h}$ ) in the culture media. These data confirmed that the culture of adipose tissue explants was associated with an increase in $\mathrm{TNF} \alpha$ production. Data also showed an increase in anaerobic glycolysis in explants. This last observation was reminiscent of a hypoxic state.

\section{Analysis of adipocyte lipolysis}

Lipolysis is a very important metabolic function of adipose tissue which can be regulated by different hormones and neurotransmitters (20). In order to determine whether culture of adipose tissue explants could influence the integrity of cell function, the lipolytic 
activity of adipocytes isolated from the explants was measured before and after $48 \mathrm{~h}$ culture. When compared with time 0 of culture, a significant increase (1.8 fold) in basal lipolysis was observed after $48 \mathrm{~h}$ culture (Figure $1 \mathrm{~A}$ ). In addition, the concentration-dependent activation of lipolysis by the $\beta$-adrenergic agonist isoproterenol revealed no significant decrease in maximal effect with no changes in EC50 (0.22 and $0.19 \mu \mathrm{M}$ at time 0 and time $48 \mathrm{~h}$ respectively) (Figure 1B). In addition, activation of lipolysis by the adenylylcyclase activator forskolin was not altered (not shown). In parallel, no significant alteration in the mean diameter of isolated adipocytes between $0(88.8 \pm 1.2 \mu \mathrm{m} \mathrm{n}=5)$ and $48 \mathrm{~h}(88.2 \pm 0.8 \mu \mathrm{M} n=5)$ culture was observed. These data showed that the functional (i.e. lipolytic process) and morphological integrity of isolated adipocytes were not dramatically altered by primary culture of adipose tissue explants.

\section{Analysis of gene expression.}

In order to determine whether culture of adipose tissue explants could influence adipocyte gene expression, the relative level of several mRNAs was analyzed in isolated adipocytes. As shown in Figure 2, primary culture was associated with a dramatic and timedependent decrease in the amount of several mRNAs encoding for proteins specifically expressed in adipocyte: Adipocyte Lipid Binding Protein (ALBP), Lipoprotein Lipase (LPL), Hormone Sensitive Lipase (HSL) (Figure 2A), and Peroxisome Proliferation Activating Receptor $\gamma$-2 (PPAR $\gamma 2$ ) (Figure 2B). These down-regulations were associated with a dramatic increase in the level of several other mRNAs: $\beta$-actin (Figure 2A), TNF $\alpha$, Glucose transporter-1 (Glut-1) and Hypoxia Induced Factor-1 $\alpha$ (HIF-1 $\alpha$ ) mRNAs (Figure 2B). In the same time no variation in the level of cyclophilin mRNA was observed (Figure 2B). These results showed that primary culture of adipose tissue explants was associated with important alterations in gene expression. Down-regulation of ALBP, HSL, LPL, and PPAR $\gamma 2$ mRNAs 
was reminiscent of an induction of adipocyte dedifferentiation process. Up-regulations of Glut-1 and HIF-1 $\alpha$ mRNAs were reminiscent of a hypoxic state.

\section{Involvement of TNFa in culture-induced adipocyte dedifferentiation}

As described above, the culture of adipose tissue explants was associated with an accumulation of TNF $\alpha$ in the culture medium. This accumulation was associated with a timedependent increase in adipocyte $\mathrm{TNF} \alpha \mathrm{mRNA}$ level (Figure $2 \mathrm{~B}$ ). $\mathrm{TNF} \alpha$ is a cytokine known to exert a powerful inhibitory effect on adipocyte differentiation (16-18). In order to test the potential involvement of $\mathrm{TNF} \alpha$ in culture-induced adipocyte dedifferentiation, adipose tissue explants were cultured in the presence of a phosphodiesterase inhibitor, a family of molecule which, by increasing intracellular cAMP, inhibit $\operatorname{TNF} \alpha$ production $(21,22)$. For the present study we used the phosphodiesterase inhibitor isobutylmethylxanthin (IBMX), which has previously be demonstrated to suppress endogenous production of $\mathrm{TNF} \alpha$ in human preadipocytes (23). IBMX (100 $\mu \mathrm{M})$ strongly reduced the accumulation of TNF $\alpha$ in the culture medium after $48 \mathrm{~h}$ culture $(33.1 \pm 13.5 \mathrm{pg} / \mathrm{ml} / \mathrm{g}$ of tissue $\mathrm{n}=5)$. IBMX also prevented the increase in adipocyte $\mathrm{TNF} \alpha \mathrm{mRNA}$ level observed after $48 \mathrm{~h}$ culture (Figure $3 \mathrm{~A}$ ). In parallel, IBMX prevented the reduction in ALBP, HSL (Figure 3B) and PPAR $\gamma 2$ (Figure 3A) mRNA levels, as well as the increase in $\beta$-actin mRNA level (Figure 3B), observed after $48 \mathrm{~h}$ culture. The protective effect generated by IBMX was also observed with the same extend with agents that increase cAMP such as the adenylyl cyclase activator forskolin (not shown). These data showed the involvement of cAMP in culture-induced adipocyte dedifferentiation. 


\section{Discussion}

The present study shows that primary culture of human adipose tissue explants leads to dramatic alterations in adipocyte gene expression reminiscent of a dedifferentiation process.

Evidences for a culture-induced dedifferentiation process is based on several observations. We observed that primary culture of adipose tissue explants is associated with a dramatic down-regulation of several mRNA encoding for several proteins specifically involved in the acquisition of the adipocyte phenotype such as ALBP, LPL, HSL. Moreover, culture was also associated with a dramatic reduction in the level of mRNA encoding for $\operatorname{PPAR} \gamma 2$, an adipocyte-specific transcriptional factor involved in adipocyte differentiation process (24). Finally, culture was associated with an increase in $\beta$-actin mRNA, which was previously shown to be inversely correlated with adipocyte differentiation status (25). Although alteration of gene expression reminiscent of dedifferentiation of adipocytes is obvious, it was not associated with major alteration in adipocyte functionality and morphology (cell size). Indeed, no major changes in the lipolytic activity of adipocytes isolated from the explants after $48 \mathrm{~h}$ were observed. This could be in apparent contradiction with the dramatic reduction in HSL mRNA after the same period of culture. The difference of turn-over between the HSL mRNA and HSL protein, as previously demonstrated (26), could explain the result. One could expect that, after a longer period of culture (more than $48 \mathrm{~h}$ ), HSL protein would also finally be reduced. This would also likely be the case for the other adipocyte proteins (ALPB, LPL and others) and would lead, after several days of culture, to alterations in adipocyte functions. Previous reports have shown that it is indeed possible to induce a phenotypic dedifferentiation of rat or human adipocytes by forcing them to attach on a culture dish $(27,28)$. This in vitro dedifferentiation is a relatively slow process characterized by a noticeable delipidation (occurring after 2-3 days of culture) followed by the proliferation of some of the delipidated cells (occurring 7 to 10 days of culture). Preliminary experiments 
in our laboratory indeed show that, after 7 to 10 days of culture, numerous adherent cells that exhibit a fibroblastic morphology with lipid droplets in their cytoplasm, are present underneath each explant (Gesta et al. personal data). These observations are likely characteristic of a dedifferentiation process.

What could be the mechanisms involved in this dedifferentiation process?

One possibility is the involvement of $\mathrm{TNF} \alpha$, a cytokine known to inhibit and reverse adipocyte differentiation in part by inducing a down-regulation of PPAR $\gamma 2$ expression (16-18, 29). Our results show a time-dependent increase in adipocyte $\mathrm{TNF} \alpha \mathrm{mRNA}$ level as well as an accumulation of $\mathrm{TNF} \alpha$ in the culture medium. We also observed that culture was associated with a slight but significant increase in basal adipocyte lipolysis, without modification of the $\beta$-adrenergic-dependent lipolysis. Similar alteration of lipolysis was observed in rat adipocytes exposed to $\mathrm{TNF} \alpha(30)$. Finally, our results show that it is possible to prevent culture-induced adipocyte dedifferentiation by treating explants with IBMX. The inhibitory action of IBMX on TNF $\alpha$ production has been reported in other cell types such as monocytes $(21,22)$ and also in preadipocytes (23) and results from its ability to increase intracellular cAMP, a powerful regulator of $\mathrm{TNF} \alpha$ transcription (31-33). Whereas our observations suggest the involvement of TNF $\alpha$ in the dedifferentiation process induced by culturing human adipose tissue explants, further complementary experiments (such as the use of blocking $\mathrm{TNF} \alpha$ antibodies) will have to be performed to prove this hypothesis.

Another possible event involved in the dedifferentiation process induced by culturing human adipose tissue explants, is hypoxia. We indeed observed that the culture of adipose tissue explants was associated with an increase in the anerobic glycolysis of the adipocytes. In parallel, we observed an increase in the level of mRNA encoding for Glut-1, a protein responsible for the increase in basal glucose transport observed in anaerobic glycolysis (34, 35). In parallel, we also observed an increase in the level of mRNA encoding for HIF-1 $\alpha$, a 
transcriptional factor tightly regulated by $\mathrm{O} 2$ concentration (36) and which controls the expression of several hypoxia-sensitive genes including Glut-1 (37). Whereas HIF-1 $\alpha$ mRNA is constitutively expressed in cultured cells, it is markedly increased by hypoxia $(38,39)$. Therefore, our data strongly suggest that, in our culture conditions, adipocytes isolated from the explants were in a relative hypoxia. Such a conclusion was expected since adipose tissue explants are issued from a surgery which disconnect the tissues from blood flow and from $\mathrm{O} 2$. Nevertheless, definitive demonstration of the involvement of hypoxia in the dedifferentation process induced by culturing human adipose tissue explants, will require further experiments. For example, it will be of particular interest to test the influence of increased oxygen concentration in the culture medium on adipocyte gene expression.

Hypoxia has been reported to be associated with an increase in TNF $\alpha$ production in some cell types (40-42). Hypoxia effect on TNF $\alpha$ is mediated by a reduction of cAMP (43, 44) leading in turn to an inhibition of the cAMP Responsive Element Binding protein, a transcriptional factor that negatively regulates $\mathrm{TNF} \alpha$ gene expression (45). It is possible that the hypoxia observed when adipose tissue explants are set in culture could be responsible to the increase in adipocyte $\mathrm{TNF} \alpha$ expression and secretion.

In parallel to $\mathrm{TNF} \alpha$ and hypoxia one cannot exclude the involvement of other factors or envents. We observed that, even after a ten-fold reduction in the amount of adipose tissue explants in the same volume of culture medium down-regulation of adipocyte gene expression persisted (Gesta, personal data). This observation does not favor the involvement of a depletion of some medium compounds such as glucose or seric factors in the dedifferentiation process induced by culturing human adipose tissue explants

In conclusion, the results of the present study have to be taken in consideration when the culture of adipose tissue explants is used to study regulation of adipocyte gene expression. 
Investigators have to be aware that the simple fact to set adipose tissue explants in culture generates profound alterations in adipocyte gene expression. 


\section{References}

1. Smith U, Jacobsson B. Studies of human adipose tissue in culture. II. Effects of insulin and of medium glucose on lipolysis and cell size. Anat Rec 1973;176(2):181-3.

2. Smith U. Morphologic studies of human subcutaneous adipose tissue in vitro. Anat Rec 1971;169(1):97-104.

3. Robertson JP, Faulkner A, Vernon RG. Regulation of glycolysis and fatty acid synthesis from glucose in sheep adipose tissue. Biochem J 1982;206(3):577-86.

4. Fried SK, Russell CD, Grauso NL, Brolin RE. Lipoprotein lipase regulation by insulin and glucocorticoid in subcutaneous and omental adipose tissues of obese women and men. J Clin Invest 1993;92(5):2191-8.

5. Ottosson M, Vikman-Adolfsson K, Enerback S, Olivecrona G, Bjorntorp P. The effects of cortisol on the regulation of lipoprotein lipase activity in human adipose tissue. J Clin Endocrinol Metab 1994;79(3):820-5.

6. Russell CD, Petersen RN, Rao SP, Ricci MR, Prasad A, Zhang Y, et al. Leptin expression in adipose tissue from obese humans: depot-specific regulation by insulin and dexamethasone. Am J Physiol 1998;275(3 Pt 1):E507-15.

7. Halleux CM, Servais I, Reul BA, Detry R, Brichard SM. Multihormonal control of ob gene expression and leptin secretion from cultured human visceral adipose tissue: increased responsiveness to glucocorticoids in obesity. J Clin Endocrinol Metab 1998;83(3):902-10.

8. Rieusset J, Andreelli F, Auboeuf D, Roques M, Vallier P, Riou JP, et al. Insulin acutely regulates the expression of the peroxisome proliferator- activated receptorgamma in human adipocytes. Diabetes 1999;48(4):699-705. 
9. Alessi MC, Peiretti F, Morange P, Henry M, Nalbone G, Juhan-Vague I. Production of plasminogen activator inhibitor 1 by human adipose tissue: possible link between visceral fat accumulation and vascular disease. Diabetes 1997;46(5):860-7.

10. Morange PE, Aubert J, Peiretti F, Lijnen HR, Vague P, Verdier M, et al. Glucocorticoids and insulin promote plasminogen activator inhibitor 1 production by human adipose tissue. Diabetes 1999;48(4):890-5.

11. Viguerie-Bacands N, Saulnier-Blache J, Dandine M, Dauzats M, Daviaud D, Langin D. Increase in Uncoupling Protein-2 mRNA expression by BRL49653 and bromopalmitate in human adipocytes. Biochem Biophys Res Com 1999;256:138-141.

12. Gorzelniak K, Janke J, Engeli S, Sharma AM. Validation of endogenous controls for gene expression studies in human adipocytes and preadipocytes. Horm Metab Res 2001;33(10):625-7.

13. Hotamisligil GS, Shargill NS, Spiegelman BM. Adipose expression of tumor necrosis factor-alpha: direct role in obesity-linked insulin resistance. Science $1993 ; 259(5091): 87-91$.

14. Hotamisligil GS, Arner P, Caro JF, Atkinson RL, Spiegelman BM. Increased adipose tissue expression of tumor necrosis factor- $\alpha$ in human obesity and insulin resistance. J. Clin. Invest. 1995;95:2409-2415.

15. Kern PA, Saghizadeh M, Ong JM, Bosch RJ, Deem R, Simsolo RB. The expression of tumor necrosis factor in human adipose tissue. Regulation by obesity, weight loss, and relationship to lipoprotein lipase. J. Clin. Invest. 1995;95:2111-2119.

16. Torti FM, Dieckmann B, Beutler B, Cerami A, Ringold GM. A macrophage factor inhibits adipocyte gene expression: an in vitro model of cachexia. Science $1985 ; 229(4716): 867-9$. 
17. Roncari DA, Le Blanc PE. Inhibition of rat perirenal preadipocyte differentiation. Biochem Cell Biol 1990;68(1):238-42.

18. Petruschke T, Hauner $H$. Tumor necrosis factor- $\alpha$ prevents the differentiation of human adipocyte precursor cells and causes delipidation of newly developed fat cells. J. Clin. Endocrinol. Met. 1993;76:742-747.

19. Bradley DC, Kaslow HR. Radiometric assays for glycerol, glucose, and glycogen. Anal. Biochem. 1989;180:11-16.

20. Langin D, Lucas S, Lafontan M. Millennium fat-cell lipolysis reveals unsuspected novel tracks. Horm Metab Res 2000;32(11-12):443-52.

21. Seldon PM, Barnes PJ, Meja K, Giembycz MA. Suppression of lipopolysaccharide-induced tumor necrosis factor-alpha generation from human peripheral blood monocytes by inhibitors of phosphodiesterase 4 : interaction with stimulants of adenylyl cyclase. Mol Pharmacol 1995;48(4):747-57.

22. Schmidt-Choudhury A, Furuta GT, Lavigne JA, Galli SJ, Wershil BK. The regulation of tumor necrosis factor-alpha production in murine mast cells: pentoxifylline or dexamethasone inhibits IgE-dependent production of TNF-alpha by distinct mechanisms. Cell Immunol 1996;171(1):140-6.

23. Hube F, Lee YM, Rohrig K, Hauner H. The phosphodiesterase inhibitor IBMX suppresses TNF-alpha expression in human adipocyte precursor cells: a possible explanation for its adipogenic effect. Horm Metab Res 1999;31(6):359-62.

24. Tontonoz P, Hu E, Graves RA, Budavari AI, Spiegelman B. mPPAR 2 : tissuespecific regulator of an adipocyte enhancer. Genes Dev. 1994;8:1224-1234.

25. Spiegelman BM, Farmer SR. Decreases in tubulin and actin gene expression prior to morphological differentiation of 3 T3 adipocytes. Cell 1982;29(1):53-60. 
26. Sumida M, Sekiya K, Okuda H, Tanaka Y, Shiosaka T. Inhibitory effect of tumor necrosis factor on gene expression of hormone sensitive lipase in 3T3-L1 adipocytes. J. Biochem. 1990;107:1_2.

27. Cheng A, Deitel M, Roncari DA. Relative Resistance of adipocytes from massively obese persons to dedifferentiation. Obesity Surgery 1993;3:340-345.

28. Sugihara H, Yonemitsu N, Miyabara S, Toda S. Proliferation of unilocular fat cells in the primary culture. J Lipid Res 1987;28(9):1038-45.

29. Rosenbaum SE, Greenberg AS. The short- and long-term effects of tumor necrosis factor-alpha and BRL 49653 on peroxisome proliferator-activated receptor (PPAR)gamma2 gene expression and other adipocyte genes. Mol Endocrinol $1998 ; 12(8): 1150-60$.

30. Green A, Dobias SB, Walters DJA, Brasier AR. Tumor necrosis factor increases the rate of lipolysis in primary cultures of adipocytes without altering levels of hormone-sensitive lipase. Endocrinology 1994;134:2581-2588.

31. Tannenbaum CS, Hamilton TA. Lipopolysaccharide-induced gene expression in murine peritoneal macrophages is selectively suppressed by agents that elevate intracellular cAMP. J Immunol 1989;142(4):1274-80.

32. Taffet SM, Singhel KJ, Overholtzer JF, Shurtleff SA. Regulation of tumor necrosis factor expression in a macrophage-like cell line by lipopolysaccharide and cyclic AMP. Cell Immunol 1989;120(2):291-300.

33. Spengler RN, Spengler ML, Lincoln P, Remick DG, Strieter RM, Kunkel SL. Dynamics of dibutyryl cyclic AMP- and prostaglandin E2-mediated suppression of lipopolysaccharide-induced tumor necrosis factor alpha gene expression. Infect Immun 1989;57(9):2837-41. 
34. Bashan N, Burdett E, Hundal HS, Klip A. Regulation of glucose transport and GLUT1 glucose transporter expression by $\mathrm{O} 2$ in muscle cells in culture. Am J Physiol 1992;262(3 Pt 1):C682-90.

35. Bashan N, Burdett E, Guma A, Sargeant R, Tumiati L, Liu Z, et al. Mechanisms of adaptation of glucose transporters to changes in the oxidative chain of muscle and fat cells. Am J Physiol 1993;264(2 Pt 1):C430-40.

36. Wenger RH. Mammalian oxygen sensing, signalling and gene regulation. $\mathbf{J}$ Exp Biol 2000;203 Pt 8:1253-63.

37. Ebert BL, Firth JD, Ratcliffe PJ. Hypoxia and mitochondrial inhibitors regulate expression of glucose transporter-1 via distinct Cis-acting sequences. J Biol Chem $1995 ; 270(49): 29083-9$.

38. Yu A, Frid M, Shimoda L, Wiener C, Stenmark K, Semenza G. Temporal spatial, and oxygen-regulated expression of hypoxia-inducible factor-1 in the lung. Am $\mathbf{J}$ Physiol 1998;275((4 Pt 1)):L818-L826.

39. Catron T, Mendiola MA, Smith SM, Born J, Walker MK. Hypoxia regulates avian cardiac Arnt and HIF-1alpha mRNA expression. Biochem Biophys Res Commun $2001 ; 282(2): 602-7$

40. Ghezzi P, Dinarello CA, Bianchi M, Rosandich ME, Repine JE, White CW. Hypoxia increases production of interleukin-1 and tumor necrosis factor by human mononuclear cells. Cytokine 1991;3(3):189-94.

41. Scannell G, Waxman K, Kaml GJ, Ioli G, Gatanaga T, Yamamoto R, et al. Hypoxia induces a human macrophage cell line to release tumor necrosis factor-alpha and its soluble receptors in vitro. J Surg Res 1993;54(4):281-5.

42. Lim YC, Gough MJ, Homer-Vanniasinkam S, Parkin SM. Induction of tumour necrosis factor-alpha release by hypoxia. Biochem Soc Trans 1997;25(2):231S. 
43. Ogawa S, Koga S, Kuwabara K, Brett J, Morrow B, Morris SA, et al. Hypoxiainduced increased permeability of endothelial monolayers occurs through lowering of cellular cAMP levels. Am J Physiol 1992;262(3 Pt 1):C546-54.

44. Taylor CT, Lisco SJ, Awtrey CS, Colgan SP. Hypoxia inhibits cyclic nucleotide-stimulated epithelial ion transport: role for nucleotide cyclases as oxygen sensors. J Pharmacol Exp Ther 1998;284(2):568-75.

45. Taylor CT, Fueki N, Agah A, Hershberg RM, Colgan SP. Critical role of cAMP response element binding protein expression in hypoxia-elicited induction of epithelial tumor necrosis factor-alpha. J Biol Chem 1999;274(27):19447-54. 
Acknowledgements: This work was supported by grants from the Institut Nationale de la Santé et de la Recherche Médicale, the Institut de Recherche Servier, the Association pour la Recherche sur le Cancer (\#5381) and the Laboratoires Clarins. 
Legend of the figures

Figure 1: Influence of the primary culture of human adipose tissue explants on adipocyte lipolysis. Adipocytes were isolated from adipose tissue explants by collagenase digestion before (time 0 ) and after $48 \mathrm{~h}$ culture. Lipolysis was determined by measuring the amount of glycerol released by isolated adipocytes in the absence (A) or in the presence (B) of increasing concentration of isoproterenol. Values are means \pm SE from 9 separate experiments. $* \mathrm{P}<0.05$ when comparing with time 0 of culture (ANOVA).

Figure 2: Influence of the primary culture of human adipose tissue explants on adipocyte gene expression. Adipocytes were isolated from adipose tissue explants by collagenase digestion before (time 0 ) and after 3, 6, 24, and 48h primary culture. RNA were extracted from isolated adipocytes and mRNAs were analyzed by Northern-blot analysis (A) and RT-PCR (B). Representative of 9 separate experiments.

Figure 3: Influence of IBMX on adipocyte gene expression. Adipocytes were isolated from adipose tissue explants by collagenase digestion before (time 0 ) and after $48 \mathrm{~h}$ primary culture. RNA were extracted from isolated adipocytes and mRNAs were analyzed by RT-PCR (A) and Northern-blot analysis (B). Representative of 5 separate experiments. 